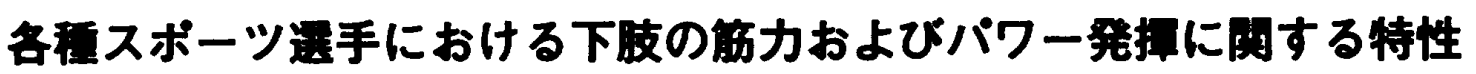 \\ 図子浩 二1) 高松薰 ${ }^{2)}$ 古藤高 良 ${ }^{2)}$
}

\section{The specificity of leg strength and power in several sport athletes}

\author{
Koji Zushi ${ }^{1}$ Kaoru Takamatsu ${ }^{2}$ and Takayoshi Kotoh ${ }^{2}$
}

\begin{abstract}
Abstraet
This study clarified the specificity of leg strength and power in several sport athletes. To accomplish this purpose, a new physical fitness test was developed to evaluate the capacity for the ballistic and stretch-shortening cycle (SSC) movements.

1. The drop jump (DJ), a typical SSC movement was used in this test. A few experiments were performed to determine the best dropping height and jumping technique of $D J$ in 10 college male athletes. These results showed the best method of DJ was rebound DJ with small angular displacement of the knee from $0.3 \mathrm{~m}$ because of appearing the shortest contact time and the longest air time, and being ballistic and safe movement.

2. Average force $\left[F_{\text {index }}=\left\{t_{a} / 2+\left(2 \cdot h_{d} / g\right)^{1 / 2}\right\} / t_{c}+1\right]$, average power $\left[P_{\text {index }}=\mid g \cdot\right.$ $\left.\left(t_{a} / 2\right)^{2}-2 \cdot h_{d} \mid /\left(2 \cdot t_{c}\right)\right]$ and the capacity to jump higher within shorter contact time $\left[D J_{\text {index }}\right.$ $\left.=\left(1 / 8 \cdot g \cdot t_{a}{ }^{2}\right) / t_{c}\right]$ are calculated by using contact time $\left(t_{c}\right)$, air time $\left(t_{a}\right)$ and dropping height $\left(h_{d}\right)$ of DJ, and $g\left(9.81 \mathrm{~m} / \mathrm{s}^{2}\right)$. Interrelationships between $D J_{\text {index }} F_{\text {index }}, P_{\text {index }} t_{c}$ and $t_{a}$ were examined in 93 male athletes of 14 sport events. These results showed the best index was $D J_{\text {index }}$ because of reflecting both $F_{\text {index }}$ and $P_{\text {index. }}$ and $t_{c}$ and $t_{a}$.

3. The specificity of leg strength and power was investigated by comparing with $\mathrm{DJ}_{\mathrm{in}}$ dex height of counter movement jump $(\mathrm{CMJ}-\mathrm{H})$ and maximum strength exerted by squat posture at $90^{\circ}$ of knee angle (S-MAX) in 93 male athletes of 14 sport events. This result showed all sport athletes were grouped into $A, B$ and $C$ type. Jumper and sprinter, gymnast and kendo atheletes belonged to $A$ type which showed the character of large in order of $\mathrm{DJ}_{\text {index }}, \mathrm{CMJ}-\mathrm{H}$ and S-MAX. Skater, ski jumper and swimmer belonged to $\mathrm{B}$ type which showed contrary character of $A$ type. Ball game player and long distance runner belonged to $C$ type which did not show difference among them. But excellent players for jump and footwork in ball games showed the same character as jumper and sprinter.

These results lead to the conclusion that we should evaluate not only the general leg strength and power but also the capacity for the ballistic and SSC movement by measuring $\mathrm{DJ}_{\text {index }}$ when coaches scout for sport talents and athletes practice the training according to specificity of strength and power. It should also be added that $\mathrm{DJ}_{\text {index }}$ is a practical index which can be simply and exactly measured by using matswitch.
\end{abstract}

1) 筑波大学大学院体育科学研究科 テ305 つくば市天王台 1-1-1

2) 筑波大学体育科学系 于305つくば市天王台 1-1-1
1. Doctoral Program of Health and Sport Sciences, University of Tsukuba 1-1-1 Tennohdai. Tsukuba. Ibaraki. Japan (305)

2. Institute of Health and Sport Sciences, University of Tsukuba 1-1-1 Tennohdai, Tsukuba, Ibaraki, Japan (305) 
Key words : ballistic movement, stretch-shortening cycle movement, drop jump, strength, power

(Japan J. Phys. Educ., $38: 265-278$, November, 1993)

\section{繗}

陸上競技の跳躍種目における走幅跣や走高跳 は, 踏切時間が0.1秒から 0.2 秒と極めて短く 20.21)，短い時間内に大きな力を集中的に発揮す る運動である。また，球技スポーツにおける各種 の跳躍やフットワークにも，これらに類似した革 動が内在していると考えられる．このような力を 漛発的に極限まで発揮する運動は，バリスティッ ク運動 (ballistic movement)と呼ばれ，運動遂行 時間が比較的長い運動やゆっくりと力を調節しな がら発揮する運動とは，神経制御機棬や力発揮に 関する調節機序がかなり異なる $9.15-17,26,33)$

一方，走幅跳や走高跳は，筋の収編様式からみ ると、高蚛度のエキセントリックな収縮がコンセ ントリックな収縮に先立って生じる典型的な伸張 一短縮サイクル運動 (stretch shortening cycle exercise)である ${ }^{24.25)}$.この伸張一短縮サイクル连 動は，伸張反射機構や弾性エネルギーの眝蔵およ び再利用機構などの神経・箭・健系の調節機構が 有効に伤き，運動初期から大きな力を急激に発揮 できたり，あるいは連動効率をよくすることがで きる1,5.6.8.11-14.18.23-25.31)

上述のことは，走幅跣や走高跳，あるいは球技ス ポーツにおける各種の囉やフットワークを有効 に遂行するためには，バリスティック運動と伸張 一短縮サイクル運動の二つの運動を有氻に遂行で きる総合的な能力が必要であることを示している.

一般に，下肢の筋力の测定には，スクワット運 動や㮏伸展運功による最大挙上重量などが用いら れ，下肢のパワーの測定には，垂直跌の跣躍高や 立偪跳の跳躍距などが用いられている。これら を運動遂行時間と筋の収縮様式からみると，前者 では，運㘯時間の制的を受けずに，主にコンセン トリックおよびアインメトリックな筋収縮によっ て発揮できる力の上限を評価している。これに対 して, 後者では, 垂直跣の踏切時間が浅い滕曲げ
動作の場合には0.546秒，深い㮏曲げ動作の場合 には0.873秒であることから ${ }^{30)}$ ，比較的長い運動 遂行時間内に低強度の伸張 - 短樎サイクル運動に よって発揮できる力積の大きさを評価していると 考えられる.このことは，立幅跳についても同様 である.したがって，一般に行われている筋力ゃ パワーの测定では，陸上競技の跳躍能力，あるい は球技スポーツにおける各種の跳躍やフットワー クを有効に遂行する能力を，必ずしも適切に評価 することはできないと考えられる。

そこで本研究では, バリスティックな伸張 - 短 縮サイクル運動の遂行能力を, 高度な精密测定機 器を使わずに, スクワット運動や垂直跳と同様に 一般的な体力テストとして，だれでも，いつでも， どこでも，簡単に，测定し評価できるテスト方法 について検討した.このために，典型的なバリス ティックな伸張 - 短維サイクル運動であるドロッ プジャンプにおける踏切時間と跳躍時間の 2 変数 のみを利用して，力学的に算出できる踏切中の平 均力と平均パワー，および䟽躍高を踏切時間で除 した值の三つの指標を作成し，それらの有効性に ついて検討した。 さらに、これらの各指標とスク ワット姿勢による筋力および垂直跌の跳躍高を比 較することによって，各種スポーツ選手における 下肢の筋力およびパワーに関する特性について検 討した。

方法

\section{1. バリスティックな伸弪一短缩サイクル通功の 遂行能力を呯洒する指模の作成}

ドロップジャンブは，スクワット姿勢から反動 なしで跱び上がる跳躍や，その場でいったんしゃ がみ込んだ後に跣び上がる垂直䟽とは，神経・ 筋・睷系の調節機汬が異なることが認められてい $3^{1.7 .25 .32,33)}$. いずれの研究においても，この違 いはドロップジャンブが典型的な伸張 - 短縮サイ クル運動であることによって生じることを指摘し 
ている，そこで本研究では，ドロッフジャンプを バリスティックな伸張 - 短縮サイクル運動の遂行 能力の評価運動として用いることにした.

ドロッブジャンプにおける踏切中の身体重心運 動の変化は，力学的にみると，運動量の変化と力 学的エネルギーの変化によってとらえることがで きる. そこで, 踏切時間 $\left(t_{c}\right)$ と跳躍時間 $\left(t_{a}\right)$, 初 期条件としての跣び下りる台高 $\left(\mathrm{h}_{\mathrm{d}}\right)$ ，および重力 加速度 $\left(\mathrm{g}=9.81 \mathrm{~m} / \mathrm{s}^{2}\right)$ を用いて，踏切中における 体重当たりの平均力 $\left(\mathrm{F}_{\text {index }}\right)$ と平均パワー $\left(\mathrm{P}_{\text {index }}\right)$ の二つの指標を，次式によって算出した。

$$
\begin{aligned}
& \mathrm{F}_{\text {index }}=\left|\mathrm{t}_{\mathrm{a}} / 2+\left(2 \cdot \mathrm{h}_{\mathrm{d}} / \mathrm{g}\right)^{1 / 2}\right| / \mathrm{t}_{\mathrm{c}}+1 \cdots(1) \\
& \mathrm{P}_{\text {index }}(\mathrm{m} / \mathrm{s})=\left|\mathrm{g} \cdot\left(\mathrm{t}_{\mathrm{a}} / 2\right)^{2}-2 \cdot \mathrm{h}_{\mathrm{d}}\right| /\left(2 \cdot \mathrm{t}_{\mathrm{c}}\right) \cdots(2)
\end{aligned}
$$

ドロッブジャンプでは, 踏切中の平均力や平均 パワーが同じであっても，技術と体力の而面を反 映した跳踓高は異なる場合がある.また一方では， 跳躍高が同じであっても，踏切前半のブレーキ動 作や緩衐動作，あるいは伸張から短縮への切り換 え動作などの優劣によって, 踏切時間はかなり異 なる場合がある．そこで本研究では跳躍時間から 求められる跳躍高と踏切時間を用いて, ドロップ ジャンプの遂行能力を評価する指標 $\left(\mathrm{DJ}_{\text {index }}\right)$ を, 次式によって算出した。

$$
D J_{\text {index }}(\mathrm{m} / \mathrm{s})=\left(1 / 8 \cdot \mathrm{g} \cdot \mathrm{t}_{\mathrm{a}}{ }^{2}\right) / \mathrm{t}_{\mathrm{c}} \cdots(3)
$$

上述の 3 つの指標は, 簡単な測定装置である マットスイッチを用いて，踏切時間と跳躍時間を 測定すれば，体育やスポーツの現場において，だ れでも，いつでも，どこでも，簡単に得ることが できる．後述するように，本研究の実験はすべて フォースプレートを用いて行った. しかし, 今後 マットスイッチを用いて行うことを考虑したため に，本研究では，フォースプレートから得られた データは，踏切時間と跳躍時間のみを利用した。

なお本研究では,台上から跨び下りた後の着地, 踏切直後の堆地, 跣躍後の着地の各時点における 姿勢は同じである，すなわちこれらの各時点にお ける身体重心高は同じであるとみなした。

2. 評価通功として用いるドロップジャンプの台 离と滕曲け功作の決定

バリスティックな伸張 - 短緶サイクル運動の遂
行能力を，適切かつ安全に評価するためには，ド ロップジャンプの台高と跳翟動作を決定する必要 がある.そのために，実験 1 では，ドロッブジャ ンプにおける台高の相違が踏切時間と跣躍時間に 及ほす影㫼について検討した。

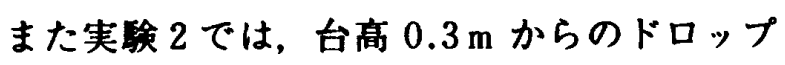
ジャンプにおける㮏曲け動作の相違が踏切時間と 跳躍時間に及ほす影㫪について検討した。

\section{(1) 被験者}

実験 1 の被験者には，大学男子体育専攻学生 10 名 $(21.0 \pm 1.1$ 藏, $174.2 \pm 4.3 \mathrm{~cm}, 68.1 \pm 4.1 \mathrm{~kg})$ を用いた，被験者の大部分は，トレーニングの場 においてドロップジャンブを経検していた。 しか し，経験数や経験したドロッフジャンプの動作は， 各被験者によって異なっていた。

実験 2 の被験者には，実験 1 の被験者の中の 3 名 $(22.0 \pm 0.0$ 藏, $174.7 \pm 3.1 \mathrm{~cm}, 69.4 \pm 1.4 \mathrm{~kg})$ を用いた。

(2) 試技方法

実験 1 と実験 2 のいずれにおいても，ドロッブ ジャンプは，腕の振込み動作の影㫼がないよう に，腰に手を当てた姿势で全力で行わせた。

実験 1 では，被呤に，0.3 m, $0.6 \mathrm{~m}, 0.9 \mathrm{~m}$, $1.2 \mathrm{~m}$ の 4 種類の台高から 3 種類の滕曲げ動作, すなわち浅い(Small-DJ) 中くらい(Middle-DJ), 深い(Large-DJ)，㮏曲け動作によるドロップジャ ンプを行わせた．実際には，各試技における滕の 最大届曲角度は, 浅い試技では $110-130^{\circ}$, 中く らいの試技では $70-90^{\circ}$ ，深い試技では $30-50^{\circ}$ の笵囲内にあった。

実験 2 では，被験者に，0.3 m の台高から様々 な㮏曲げ動作によるドロップジャンブを、十分な 休息を取らせながらランタムに25-30回行わせ た。なお試技回数は，ドロップジャンプの至適回 数を検討している先行研究 ${ }^{22)}$ をとにして決定 した.

\section{（3）測定項目および湘定方法}

実験 $1 ， 2$ ともに，踏切中の滕関節角度を左䐂 
関節外期に取り付けたコニオメータ(P and G 社 製)により，また踏切中の地面反力をフォースプ レート(Kistler 社製 AG：9821 type)により，そ

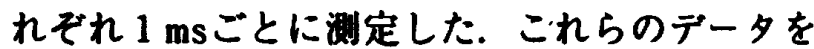
もとにして，踏切中点の滕阙節角度(滕の最大届 曲時点の角度)と，踏切時間および跳跟時間を算 出した。

\section{3. 各到ズーツ選手における下肢の觔カおよび パワー発提に阙する特性}

台高 $0.3 \mathrm{~m}$ からの浅い腅曲げ功作によるドロ ッブジャンプの $F_{\text {index, }}, P_{\text {index }}, D_{\text {index }}$ と, 垂直踥

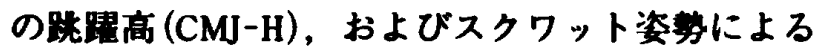
アイソメトリックな最大筋力 (S-MAX/BW) を比 较することによって，各種スポーツ選手における 下肢の筋力およびバワー発揮に関する特性につい て検討した。

\section{(1) 被験者}

被検者には，14種目のスポーツ選手93名(21.0 \pm 1.5 战, $172.5 \pm 8.0 \mathrm{~cm}, 67.3 \pm 7.5 \mathrm{~kg}$ )を用いた。 图 5 に，各スポーツ種目の旅验者数を示した。ス キージャンブ選手を除く他の種目の選手は，高い 競技水䇢を持つ大学生であった.なお,スキージャ ンブ選手は，極めて高い競技水隼を持つ日本代表 選手であった。

（2）测定項目および湘定方法

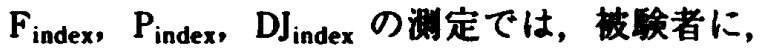
$0.3 \mathrm{~m}$ の台高からの浅い滕曲げ功作によるドロッ ブジャンブを全力で行わせた，その際に得られた 踏切時間と跳靕時間を,前述の式(1)〜(3)に代入し， $F_{\text {index, }} P_{\text {index }}, D_{\text {index }}$ を求めた.

CMJ-H の测定では，被検者に，笕の振込み功 作を用いないように，腰に手を当てた姿务で全力 で垂直踒を行わせた，その除に得られた跳既時間 をもとにして、CMJ-H を算出した。

S-MAX/BW の测定では，被験者に，滕関節角 度 $90^{\circ}$ のスクワット姿等によって，有にかついだ 固定式のシャフトを全力で 5 秒間押し上げさせ た.その祭に得られた力－時間曲線の最も高い部
分を 1 秒間にわたって平均し，S-MAX/BW を求 めた。

上述の各試技は，いずれフォースプレート (kistler 社彆 AG：9821 type) 上で行わせた。な

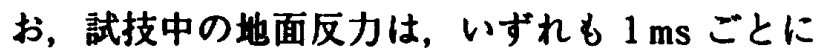
測定した。

结

果

1. ドロップジャンブにおける台高と滕曲け施作

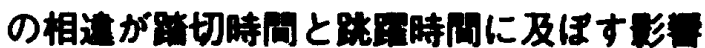

（1）台高の相遣による影喟

図 1 に，4種類の台高と 3 種類の滕曲け功作に よるドロップジャンブの踏切時間と跳躇時間を示 した.ここでは，踏切時間と跳躍時間の台高間の 差を比較するために，3 種類の榺曲げ功作ごとに 一元眍置の分散分析を行った，その結果，F值が 有意であった脖曲げ功作については，さらにライ アンの方法を用いて多重比較を行った。統計処理 の有意性は，危険事 $5 \%$ 水染で判定した。

踏切時間は，浅い滕曲げ功作の場合にのみ，台 高が高くなるほど有意に長くなった。また，跸切 時間の平均做が0.2秒以内であったのは，台高 $0.3 \mathrm{~m}$ からの浅い滕曲け動作の場合のみであっ た。囉跬間は、いずれの滕曲げ功作においても，
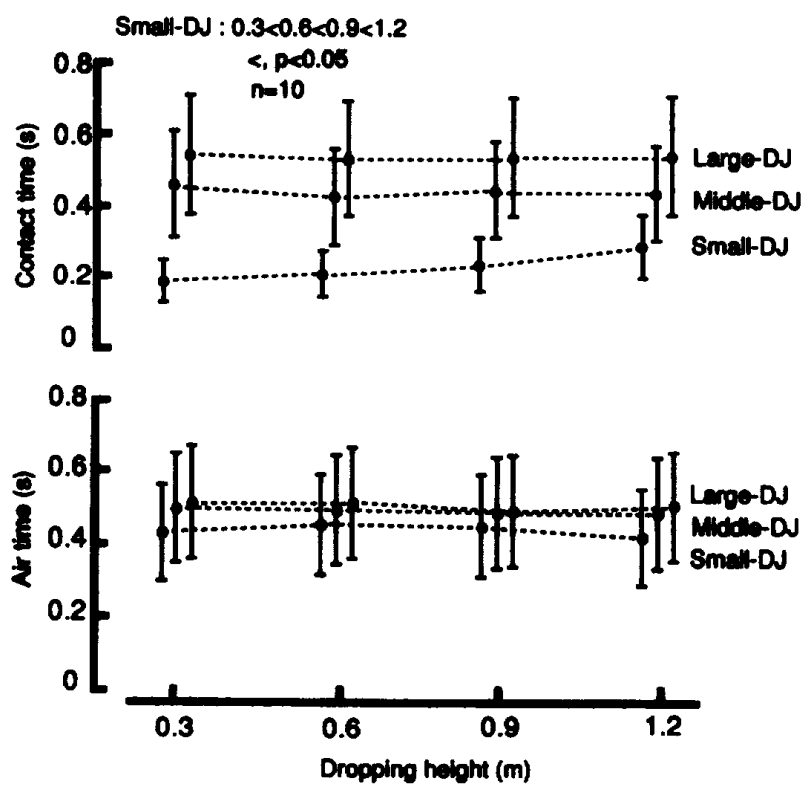

Fig 1. Contact time and air time in drop jump with small, middle, large anguler displacement of the knee from height of $0.3,0.6,0.9$ and $1.2 \mathrm{~m}$. 

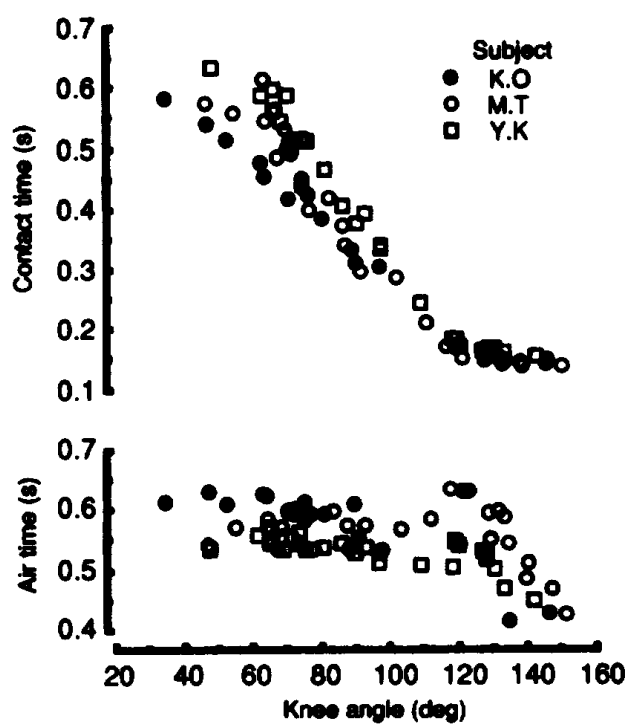

Fig 2. Relationships between knee angle at maximum flexion, and contact time and air time in drop jump from height of $0.3 \mathrm{~m}$.

台高間に有意な差はなかった。

（2）滕曲げ動作の相違による影䨳（台高 $0.3 \mathrm{~m}$ の場合)

図 2 に，様々な滕曲げ钦作によるドロッブジャ ンプの踏切中点の滕関節角度と, 踏切時間および
跳躍時間との関係を示した。

被験者 3 名ともに，踏切時間は，踏切中点の㮏 関節角度が $120^{\circ}$ までは直線的に低下し，それ以降 は一定になる傾向にあった。これに対して，跣躍

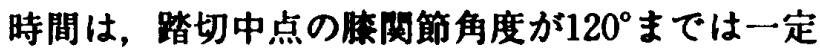
であるが，それ以降は急做に低下する頋向にあっ た.

\section{2. ドロップジャンブにおける路切時问，跳跬} 问, $F_{\text {index, }} P_{\text {index }}$, DJ $J_{\text {index }}$ の相互㜀保(台高 $0.3 \mathrm{~m}$ からの浅い滕曲(千仂作による堛合）

図 3 に，踏切時間および路躤時間と， $F_{\text {index }}$, $P_{\text {index }}, D_{\text {index }}$ との関係を示した. $F_{\text {index }}$ と踏切時 間との関係は二次曲線によく近似でき，両者間に は極めて高い有意な相関関係が認められた $(\mathrm{r}=$ $0.958 ， P<0.001)$. しかし, $F_{\text {index }}$ と跳躍時間と の間には有意な相関関係が認められたが，相関係 数は低い值であった $(r=0.456, P<0.001)$ 。こ れとは逆の結果が， $P_{\text {index }}$ と踏切時間および跳躍 時間との間に認められた，すなわち， $\mathrm{P}_{\text {index }}$ と踏 切時間との間には有意な相関関係が認められた が，相関係数は低い值であり $(\mathrm{r}=-0.269, \mathrm{P}<$ 0.05)，これに対して， $P_{\text {index }}$ と跣踓時間との
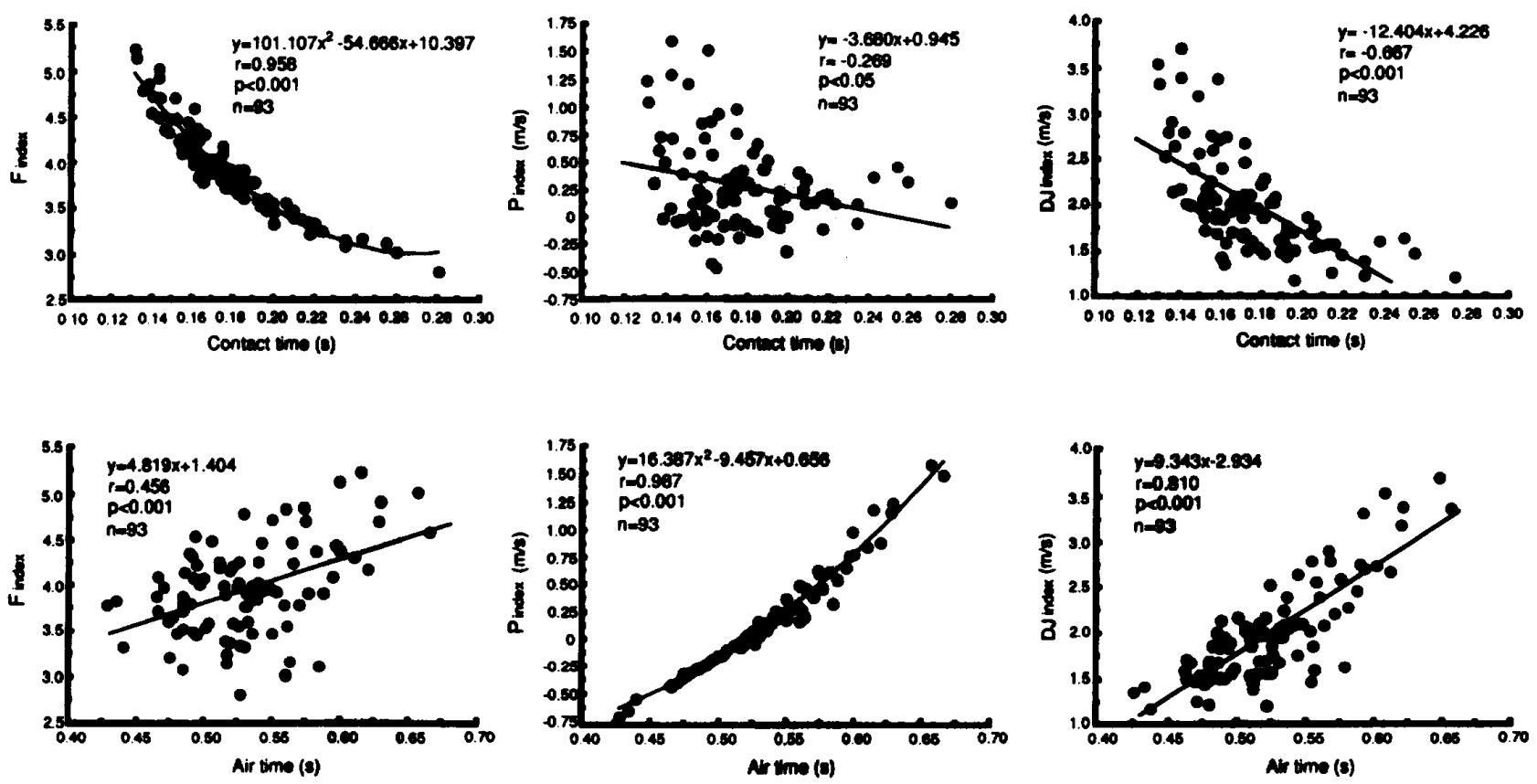

Fig 3. Relationships between contact time and air time, and $F_{\text {index. }}, P_{\text {index }}$ and $D J_{\text {index }}$ in drop jump with small angular displacement of the knee from height of $0.3 \mathrm{~m}$. 

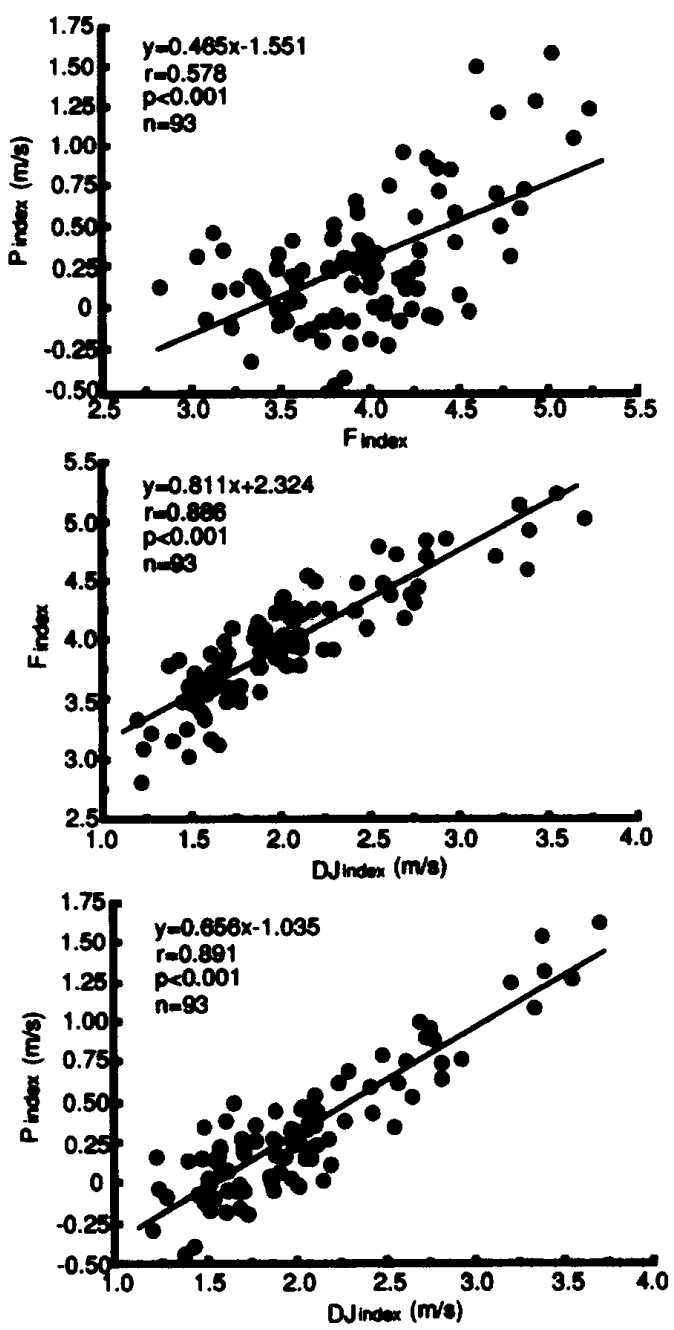

Fig 4. Relationships between $F_{\text {index. }} P_{\text {index }}$ and $\mathrm{DJ}_{\text {index }}$ in drop jump with small angular displacement of the knee from height of $0.3 \mathrm{~m}$.

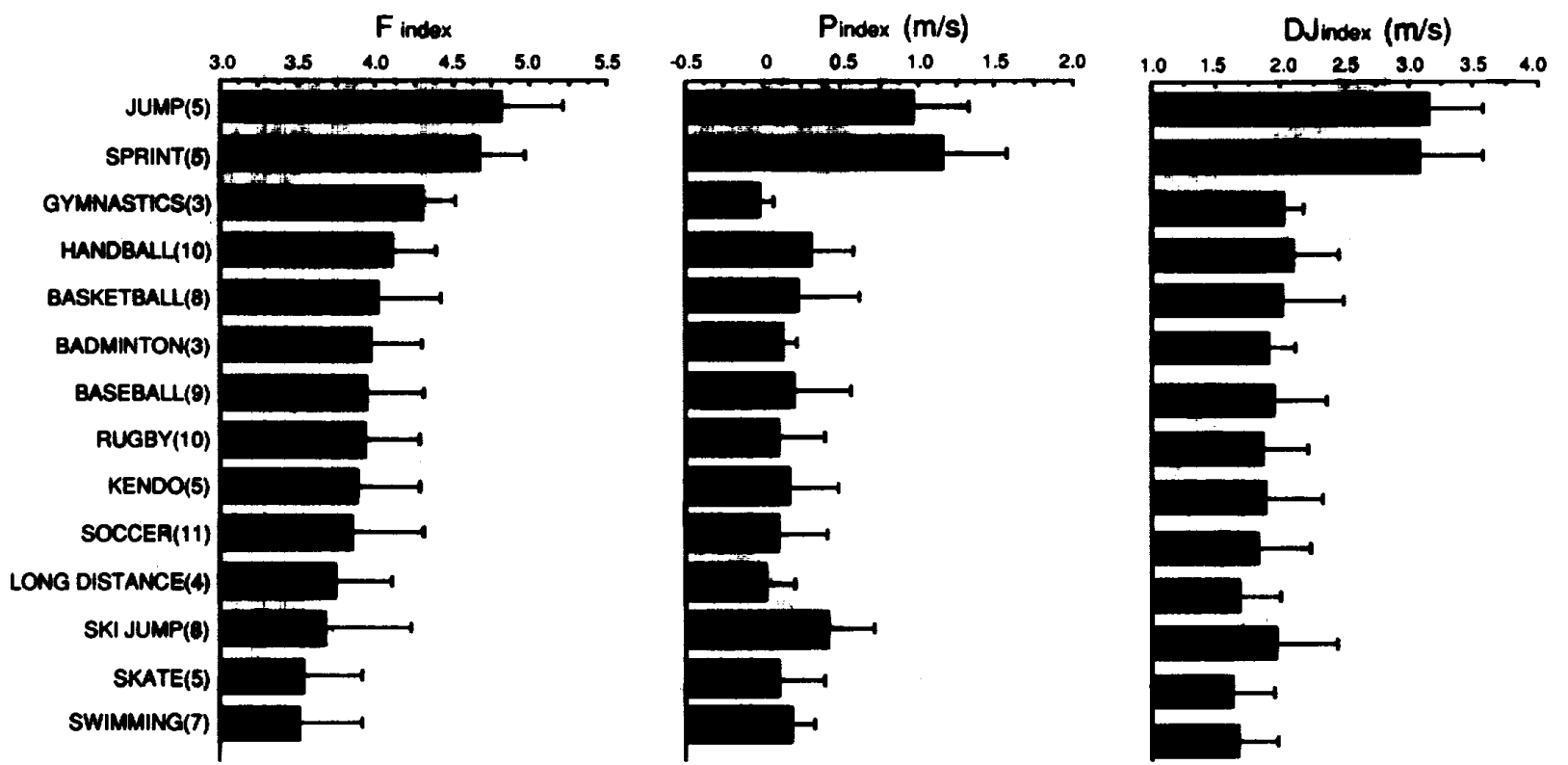

関係は二次曲線によく近似でき，西者間には枚め て高い有意な相閶関係が認められた（ $\mathbf{r}=0.987$ ， $P<0.001)$. 一方, $D_{\text {index }}$ と踏切時間 $(r=-$ $0.667, \mathrm{P}<0.001)$ ，および $\mathrm{DJ}_{\text {index }}$ と跳雖時間 $(r$ $=0.810, P<0.001)$ との間には，いずれも比較 的高い有意な相関関係が認められた。

図 4 に, $F_{\text {index }}, P_{\text {index }}, D_{\text {index }}$ の相互関係を示 した.

$F_{\text {index }}$ と $P_{\text {index }}$ との間には有意な相関関係が認 められたが，相関係数は高い值ではなかった（r $=0.578, P<0.001)$. しかし, $D_{\text {index }}$ と $F_{\text {index }}(r$ $=0.886, \mathrm{P}<0.001)$, および $\mathrm{DJ}_{\text {index }} と \mathrm{P}_{\text {index }}(\mathrm{r}$ $=0.891, P<0.001)$ との間には，いずれも有意 な高い相関関係が認められた。

\section{3. 各不スポーツ造手における下肢の觔力および} パワー発揮に開する特性

ここでは, 台高 $0.3 \mathrm{~m}$ からの浅い賋曲げ功作 によるドロップジャンプの踏切時間・䠦躍時間・

$\mathrm{F}_{\text {index }} \cdot \mathrm{P}_{\text {index }} \cdot \mathrm{DJ}_{\text {index }}, \mathrm{CMJ}-\mathrm{H}$, および S-MAX/ BW を用いて, 各種スポーツ選手における下肢の 筋力およびパワー発掉に関する特性について検討 した.

図 5 に，各種スポーツ選手におけるドロップ ジャンプの $\mathrm{F}_{\text {index }}, \mathrm{P}_{\text {index }}, \mathrm{DJ}_{\text {index }} を, \mathrm{~F}_{\text {index }}$ の高

Fig 5. $F_{\text {index, }} P_{\text {index }}$ and $D J_{\text {index }}$ in drop jump with small angular displacement of the knee from height of $0.3 \mathrm{~m}$ for several sport athletes. 

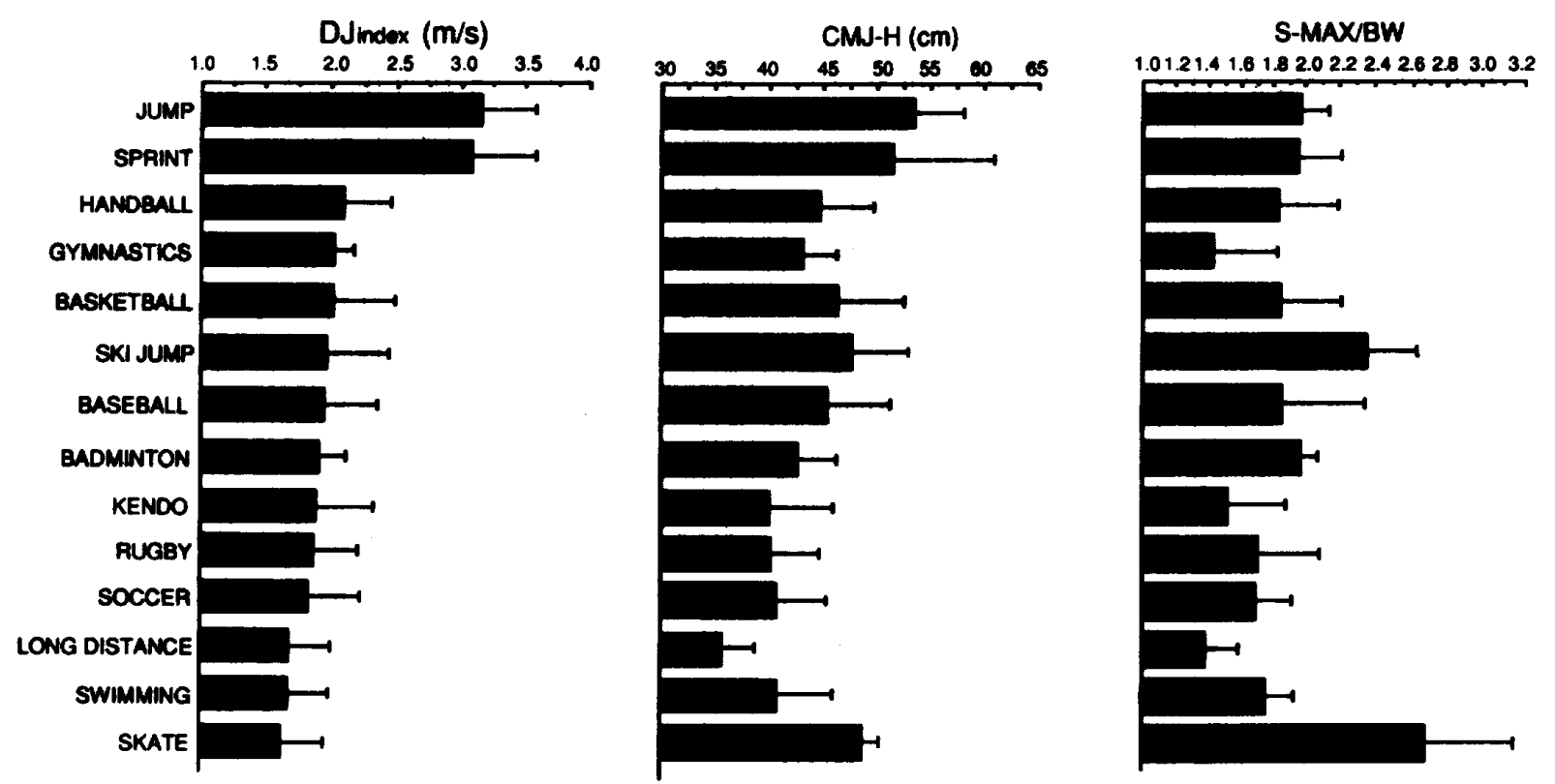

Fig 6. $\mathrm{DJ}_{\text {index }}$ in drop jump with small angular displacement of the knee from height of $0.3 \mathrm{~m}$, height of counter movement jump (CMJ-H), and maximum strenght/body weight exerted by squat posture at 90 degree of knee angle (S-MAX/BW) for several sport athletes.

い順に並べて示した。

$\mathrm{F}_{\text {index }}$ の順位と $\mathrm{P}_{\text {index }}, \mathrm{DJ}_{\text {index }}$ の順位とはかな り異なることが認められた。

図 6 に, 各種スポーツ選手におけるドロップ ジャンプの $\mathrm{DJ}_{\text {index }}, \mathrm{CMJ}-\mathrm{H}$ および S-MAX/BW を, $\mathrm{DJ}_{\text {index }}$ の高い順に並べて示した.

$\mathrm{DJ}_{\text {index }}$ の順位と $\mathrm{CMJ}-\mathrm{H}$, S-MAX/BW の順位 もかなり異なることが認められた。

$\mathrm{DJ}_{\text {index }}$ は，陸上競技の跳躍選手と短距部選手 が他の種目の選手に比较して著しく高く,ついで
ハンドボール選手, 器械体操選手,バスケットボー ル選手の順に高い值を示した. $\mathrm{CMJ}-\mathrm{H}$ は, 陸上 䅧技の跳躍選手と短距部選手が最も高く，ついで スケート選手，スキージャンブ選手，バスケット ボール選手，野球選手の順に高い値を示した。 S-MAX/BW は, スケート選手とスキージャンブ 選手が他の種目の選手に比較して著しく高く、つ いで陸上竸技の跳躍選手，バトミントン選手，陸

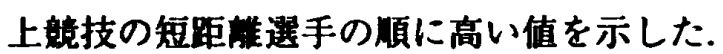

なお，図 $7 に, F_{\text {index }}, P_{\text {index }}, D_{\text {index }}$ の計算に

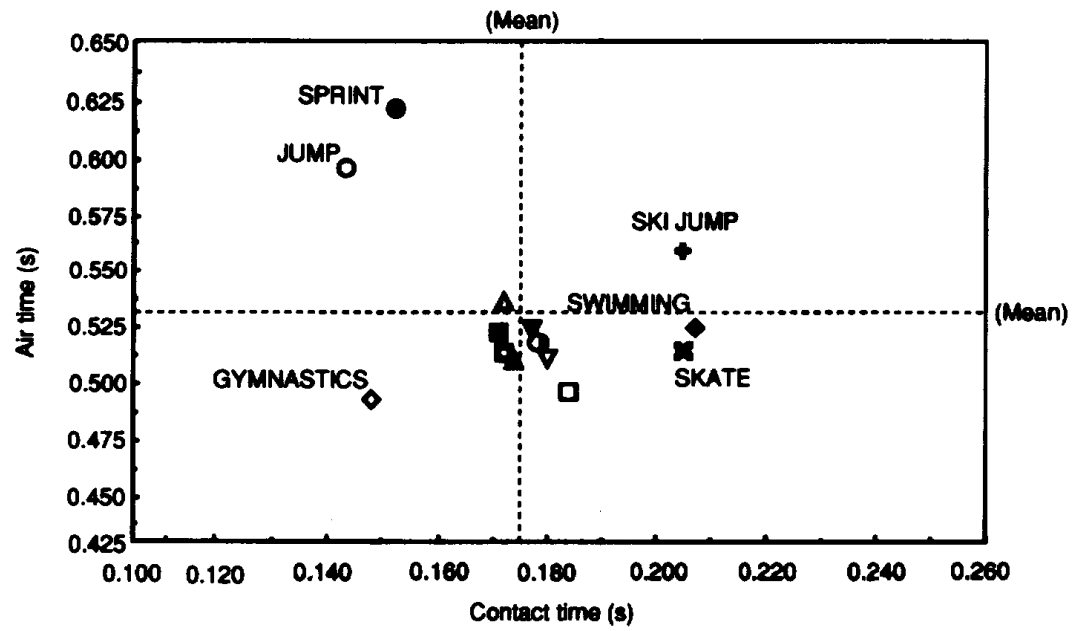

- JUMP

- SPRINT

- LONGDISTANCE

D BASKETBALL

$\triangle$ HANDBALL

A RUGBY

$\nabla$ SOCCER

$\checkmark$ BAseaAl

- grmNASTICS

- SWIMMING

- KENDO

- BADMINTON

- SKI JUMP

o'SKATE

Fig 7. Relationship between contact time and air time in drop jump with small angular displacement of the knee from height of $0.3 \mathrm{~m}$ for several sport athletes. 
選手の特性を示した.

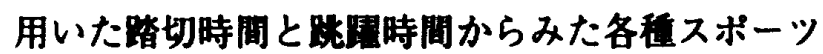

踏切時間は短いほど，跑時間は長いほど，そ れぞれの課题に対して優れていることにすると，

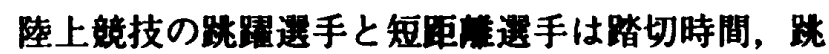
蹋時間ともに優れているタイプ、スケート選手と

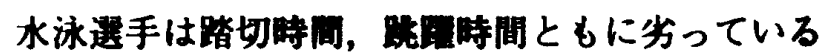

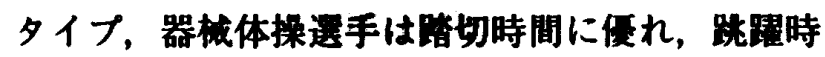
間に少っているタイフ，スキージャンブ選手は踏 切時間に劣り，踝躍時間に俆れているタイブとし て特䍩づけられた。

図 8 に,ドロップジャンプの $\mathrm{F}_{\text {index }} \cdot \mathrm{P}_{\text {index }} \cdot$ $\mathrm{DJ}_{\text {index }}, \mathrm{CMJ}-\mathrm{H}$ および S-MAX/BWをそれぞれ
標㲚得点化して，各種スポーツ選手がこれらのい ずれに優れているかを示した.ここでは，DJ ${ }_{\text {index, }}$ CMJ-H， S-MAX/BW をとにして，各種スポー ッ造手を 3 群に分けた。A群は $\mathrm{DJ}_{\text {index }}$ が最も高 く，ついで CMJ-H， S-MAX/BW の順に高い得 点を示したダループ，B 群はその逆の傾向を示し たグループ，C群はA 群とB 群のいずれにも属さ ないその他のグループとした.

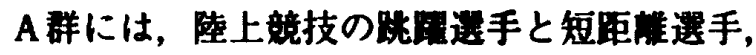
器植体操選手および剣道選手，B群には，スキー ジャンプ選手，スケート選手および水泳選手，C 群には,バスケットボール, ハンドボール，野球， ハトトントン, サッカー, ラタビーなどの球技ス

A group
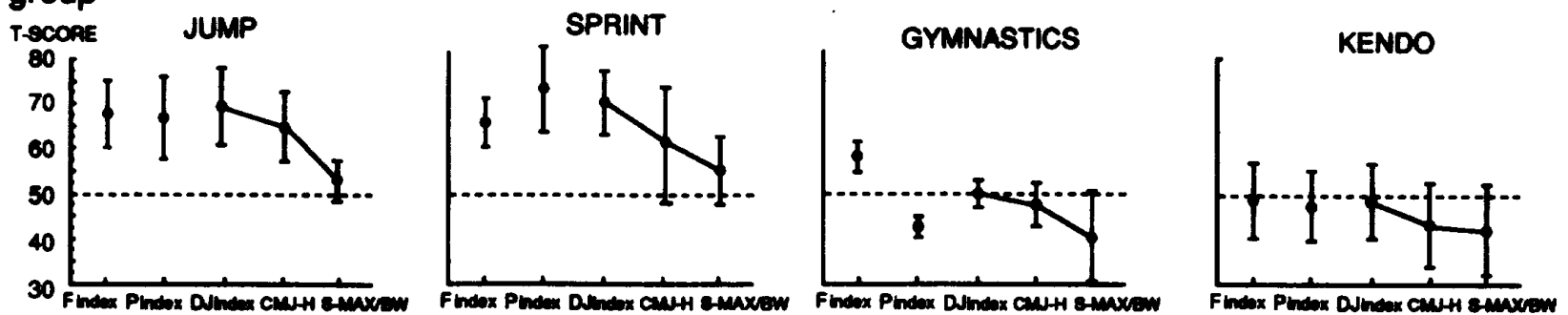

\section{$B$ group}
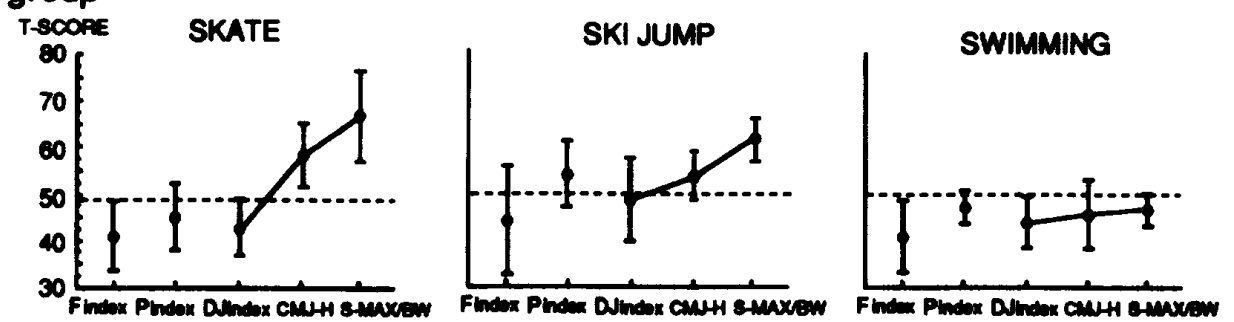

C group
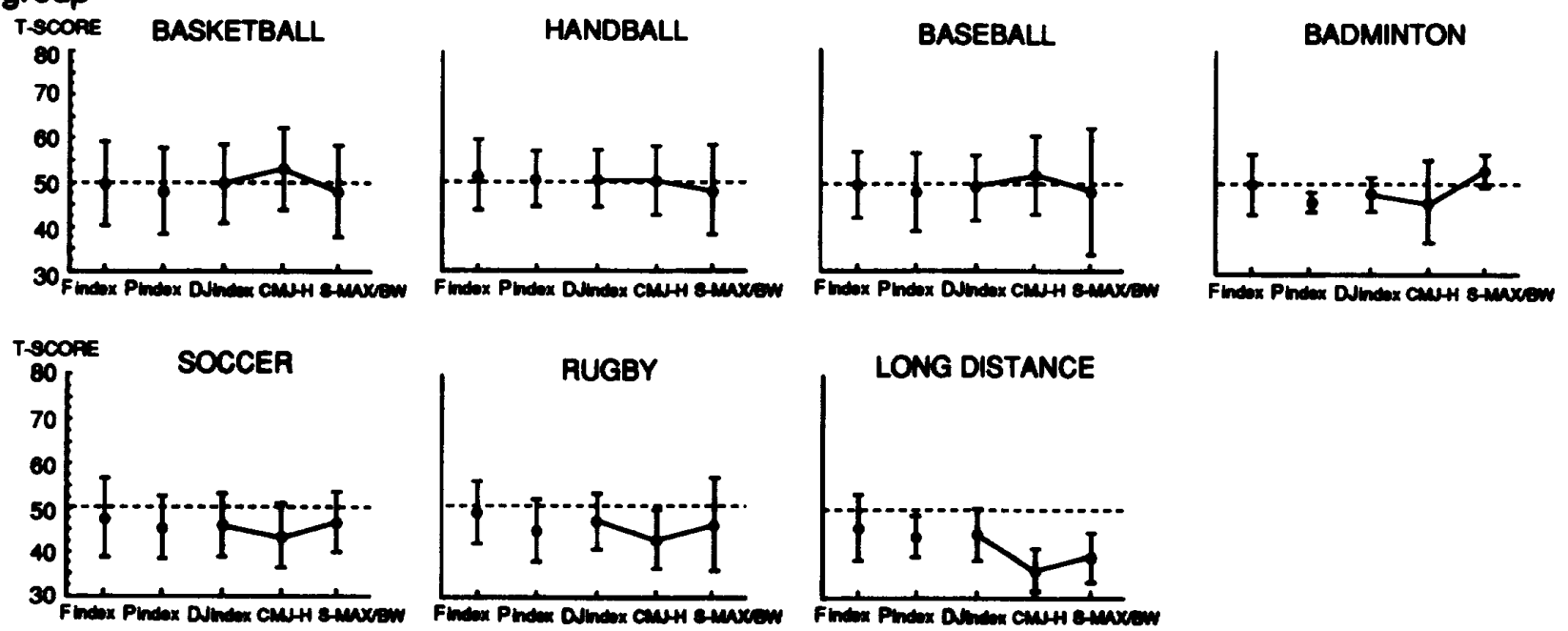

Fig 8. $T$ score of $F_{\text {index }}, P_{\text {index }}$ and $\mathrm{DJ}_{\text {index }}$ in drop jump with small angular displacement of the knee from height of $0.3 \mathrm{~m}$, height of counter movement jump $(\mathrm{CMJ}-\mathrm{H})$, and maximum strength/body weight exerted by squat posture at 90 degree of knee angle (S-MAX/BW) for several sport athletes. 


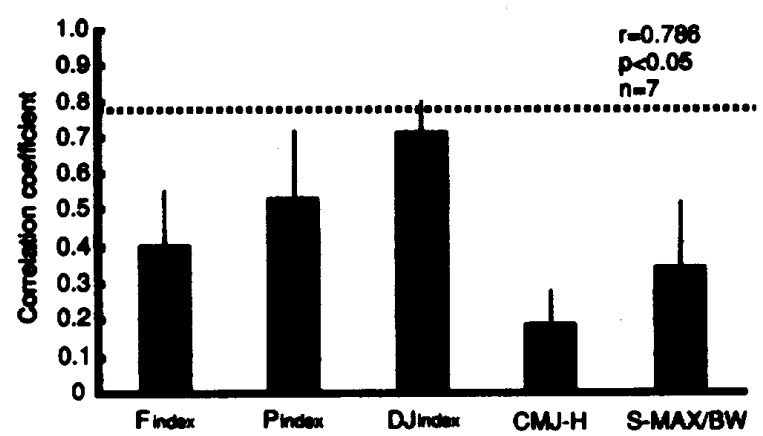

Fig 9. Spearman's correlation coefficient (by ranks) between the jump and footwork capacity in basketball depending on subjective evaluation. and $F_{\text {index. }} P_{\text {index }}$ and $D_{\text {index }}$ in drop jump with small angular displacement of the knee from height of $0.3 \mathrm{~m}$, height of counter movement jump $(\mathrm{CMJ}-\mathrm{H})$, and maximum strenght/body weight exerted by squat posture at 90 degree of knee angle (S-MAX/BW) for seven basketball players. A dotted line is significant level ; $p<0.05$.

ポーツ選手と陸上竸技の長距碓選手がそれぞれ属 した。

なお，C群に含まれろ球技スポーツ選手の中か ら，バスケットボール選手を対象して，ドロップ ジャンフの $\mathrm{F}_{\text {index }} \cdot \mathrm{P}_{\text {index }} \cdot \mathrm{DJ}_{\text {index }}, \mathrm{CMJ}-\mathrm{H}$ およ び S-MAX/BW などの指標と，実際のブレー中 における跳躍やフットワークの優劣との関係につ いて検討した。このために，まず，被験者 8 名の うち7名に対して，日常のトレーニングや試合中 における囉翟やフットワークを互いに評価させ， これらの優れる順に序列をつけさせた. ついで， この序列とドロッブジャンブの $\mathrm{F}_{\text {index }} \cdot \mathrm{P}_{\text {index }} \cdot$ $\mathrm{DJ}_{\text {index }}, \mathrm{CMJ}-\mathrm{H}$ および S-MAX/BW の各順位と の間の順位相関係数を各選手ごとに算出し，それ をもとにして平均相関係数を算出した．図 9 にそ の䊅果を示した。

跣躍やフットワークの序列と上述の各指梅との 間には，いずれも有意な平均相関係数は認められ なかった。しかし、 CMJ-H $(r=0.193, n s) p$ $\mathrm{S}-\mathrm{MAX} / \mathrm{BW}(\mathrm{r}=0.343$,ns $)$ に比较すると， $\mathrm{F}_{\text {index }}$ $(r=406, n s), P_{\text {index }}(r=0.528, n s), D J_{\text {index }}(r$ $=0.716, \mathrm{~ns})$ との平均相関係数は高く，その中で も $\mathrm{DJ}_{\text {index }}$ との平均相関係数は最も高い值であっ た.

\section{考宰

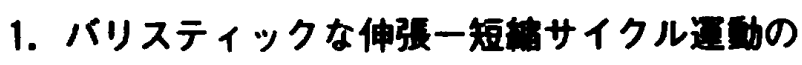 遂行能力の畔俩法 \\ (1) 評価運動として用いるドロッブジャンプの 台高と滕曲げ功作}

本研究では，まずバリスティックな伸張一短䑿 サイクル運功の遂行能力を，暗切に評価できるド ロッブジャンプの台高と滕曲げ功作について検討 した.

Brooks and Thach"), Desmedt and Godaux ${ }^{\text {15-17) }}$ は，罣動終了までの時同が0.15秒から0.20秒程度 の極めて短時間に，力を爆発的に極限まで発揮す る運功のことをバリスティック運功として定義 し，ゆっくりと力を発揮するランプ莲動や0.5秒 以上の钋い時間を要する運功とは区別している。 このバリスティック通功では，主筇の活功は外 乱によって影整されず，あらかじめ通動中枢でプ ログラムされた予定の出力量や，罣功遂行時間が 補正されずに実行されるフィードフォワード型の 神経制御機棬によって制御されている可能性が諗 められている ク運功では，運钦単位の功貝や神経街祭の発射制 度が他の逴動とは異なり，すばやい力発揮に通し たパターンになっていることも認められている 10.18.27-29)

これらのことは，バリスティックな伸張一短維 サイクル運功の遂行能力を，嗃切に测定できる台 高と禁曲け功作を决定するためには，一つには， 这功遂行時間，すなわち踏切時間を手がかりにす ることが有効であることを示している.

本研究では，ドロップジャンブにおいて，踏切 時間が陸上稖技の跣踓種目と同程度に短く，しか も0.2秒以内であったのは, 台高 $0.3 \mathrm{~m}$ からの浅 い㮏曲げ㕸作のみであることが認められた（図 1). 台高を $0.3 \mathrm{~m}$ より高くすると，踏切前半で 受け止める力学的エネルギーが大きくなるため に，踏切時間は長くなり，また，滕曲げ功作を深 くすると，垂直跣と同棁に，踏切時間は0.5秒よ りも長くなった。これらの結果は，台高の高いド ロップジャンプ，あるいは滕曲げ功作の深いドロ 
ップジャンブは, バリスティック速助の条件に合 わないことを示している.

また本砳究では，ドロップジャンブにおける踏 切時間と跣踓時間は，いずれも跨切中点の滕関節 角度が約 $120^{\circ}$ で急做に変化すること，言い换える

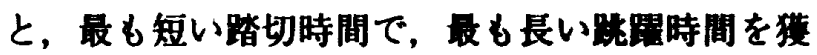
得できるドロップジャンブは，踏切中点の胰関節 角度が約 $120^{\circ}$ の场合であることが裙められた（図 2).この踏切中点の滕関節角度は，浅い滕曲げ 功作の場合と同じであった。

Bobbert et al. ${ }^{3,4)}$ は,このようなあまり高くな い台高から，浅い滕曲け功作で行うドロップジャ ンブは，身体の中の最も大きい弾性体であるアキ レス成を含む足間節を有効に利用できろので，弾 性エネルギーの貯藏および再利用機構を有奻に活 用できる運動であること，おるいは高い台高によ る場合と比䘠して，地面反力や関節にかかる力に 鋭いピークが出現しないので，安全な通動である ことなどを指接している.

本研究では，上述の理由から，バリスティック な伸張一短編サイクル荤趿の遂行能力を評価する 連功として，0.3 $\mathrm{m}$ の台高から浅い滕曲げ动作で 行うドロッブジャンプを用いることにした。

（2）バリスティックな伸張一短縮サイクル運功 の遂行能力を評価する指標

本研究では，バリスティックな伸張一短編サイ クル運功の遂行能力を評価するために, 台高 $0.3 \mathrm{~m}$ から浅い滕曲け功作で行うドロッブジャンプの踏 切時間と跳倨時間を用いて，力学的に算出できる 踏切中の平均力 $\left(\mathrm{F}_{\text {index }}\right)$ と平均バワー $\left(\mathrm{P}_{\text {index }}\right)$, お よび短い踏切時間の中で高い跳躍高を獾得する能

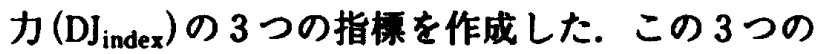
指標と踏切時間および踝蹋時間との関係をみる と， $\mathrm{DJ}_{\text {index }}$ は踏切時間および跳躇時間との間に いずれも有意な高い相関関係が認められたが, $F_{\text {index }}$ は踏切時間， $P_{\text {index }}$ は跳躍時間との間にの みに有意な高い相閶関係が認められた（图3）。ま た，3つの指標の相互関係をみると，DJ $\mathrm{J}_{\text {index }}$ は $\mathrm{F}_{\text {index }}$ および $\mathrm{P}_{\text {index }}$ との間にいずれも有意な高い 相関関係が認められたが， $F_{\text {index }}$ と $P_{\text {index }}$ との間
には高い相関関係は認められなかった（図4）。

上述の結果は， $\mathrm{F}_{\text {index }}$ と $\mathrm{P}_{\text {index }}$ は踏切時間と跣 躍時間のどちらか一方を反映しているのに对し

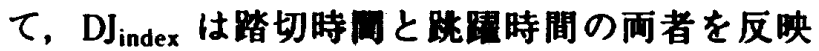
した指檍であるとともに，平均力と平均バワーの いずれも反映した指标であることを示している。 本研究では，このよろな特性を持つ $\mathrm{DJ}_{\text {index }}$ を， バリスティックな伸張一短綟サイクル運功の遂行 能力を評価する指標として用いることにした。

なお，上还したように，各指標の持つ意味が異 なるために，各種スボーツ選手における $\mathrm{F}_{\text {index, }}$ $\mathrm{P}_{\text {index }}, \mathrm{DJ}_{\text {index }}$ の大きさとその順位はかなり翼なっ たと考えられる(図 5)。

\section{2. 各和スポーツ買手における下吱の觔カおよび} パワー或挥に阙する特性

本研究では，台高 $0.3 \mathrm{~m}$ からの浅い滕曲げ旌 作におけるドロッブジャンプの $\mathrm{DJ}_{\text {index }}$, 垂直跣 の䟽䠊高 (CMJ-H)，およびスクワット姿劳による アイソメトリックな最大筋力 (S-MAX/BW)の実 测值とその標望得点化した值を用いて，各種ス ポーツ䢱手の下肢の筋力およびパワー発揮に関す ろ特性について検討した，標保得点化した值をも とにすると，本研究における被験者は大きくA， B，Cの 3 群に分けられることが認められた(図 8 ).

A 群は $\mathrm{DJ}_{\text {index }}$ が曼も高く，ついで CMJ-H, S-MAX/BW の順に高くなるタイブであり,これ

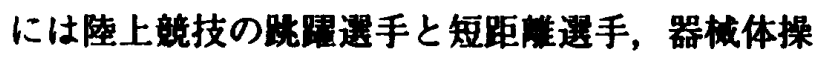
選手および剣道選手が属していた。これらのス ポーツでは，競技中におりる一功作の時間が非常 に短く，しかも勝敗を決する睡間や重要な局面で, 力を爆発的に発罩することが要求される。このよ うな各程目の特性が，上述した結果に反映された ものと考えられる.この最も影著な例は，極めて 高い $\mathrm{DJ}_{\text {index }}$ を示した陸上新技の跳踑選手と短距 部選手である(图 6 ).

一方 B 群は，A 群とは逆に，S-MAX/BW が最

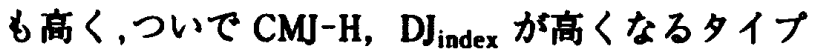
であり、これにはスケート错手，スキージャンブ 選手および水泳選手が属していた。 スケートや水 
泳には，競技中における一功作の時間が比較的長 く，ゆっくりした速度で力を発挥する局面が多い こと，竸技を行う棵境が氷上や水中であるため に，外力に抗してエキセントリックな筋力を輁発 的に発挥する場面が少ないこと，あるいは勝敗は 瞣間的な力の発揮よりも仕事の大きさに左右され ろことなどの特性がある．また，スキージャンフ には，滑走局面では，アイソメトリックな筋力を 発揮しながら，深くしゃがみこんだスクワット姿 繁を維持し，踏切局面では，できるだけ短時間に コンセントリックな筋力を発揮しながらキック功 作が行われることなどの特性がある.このような 各種目の特性が，上述した桔果に反映されたもの と考えられる，その最も影著な例は，極めて高い S-MAX/BW を示したスケート選手とスキージャ ンプ瀵手である(図6).

$\mathrm{C}$ 群は $\mathrm{DJ}_{\text {index }}, \mathrm{CMJ}-\mathrm{H}, \mathrm{S}-\mathrm{MAX} / \mathrm{BW}$ に影著な 差のない群であり，これには各種の球技スポーツ 選手および長距就選手が属していた．球技スポー ッでは，A群，B群の種目とは異なり，竸技中に 走，跣，投，打，践などの柈々な功きが要求され ろ.これらの功きには，大きな力を爆発的に発揮 することが要求されるものもあれば，大きなス ピードを出さなければならないものもある.また, そこでは,アイソメトリック,コンセントリック, エクセントリックな 3 つの觔収縮か，その埸の状 況において使い分けられる。このように，球技ス ポーツでは，棣々な能力が䅮合的に要求されるの で，上述のように特徽のない結果が得られたもの と考えられる。この結果は，ある意味では球技ス ポーツの特敗を反映している。しかし，球技スポー ツ選手の中には，他の摆手に比較して，フェイン

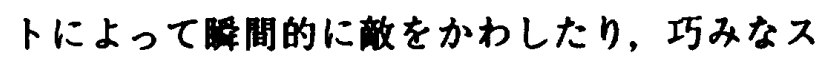
テッブをきってすばやく敇をかわしながら走り抜 けたり，跳躍することができる選手がいることも また事実である．本研究では，このような選手が どのような能力に優れているかを明らかにするた めに，跳躇やフットワークに優れる選手の序列と 各指標の順位との平均相関係数を求めた. その哧 果, 跣蹅やフットワークに優れる選手の序列とド ロップジャンブの $\mathrm{F}_{\text {index, }} \mathrm{P}_{\text {index, }} \mathrm{DJ}_{\text {index }}$ との平
均相阙係数は, $\mathrm{CMJ}-\mathrm{H}$ や S-MAX/BW に比较し て高く，その中でも $\mathrm{DJ}_{\text {index }}$ との平均相関係数は 最も高いことか認められた。この結果は，球技ス ボーツ選手か跳既やフットワークに優れるために

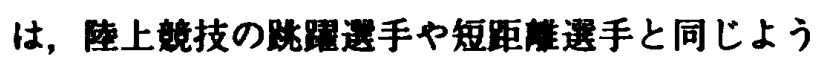
な能力を身につけていなければならないことを示 すものである.このことは，球技スボーツにおけ ろ魄踓やフットワークにも，棣々な方向へ急做に 移轩するバリスティックな伸張一短糄サイクル㯰 功が内在していることを考虑すると十分に理解で きる。

ドロッブジャンブにおける $\mathrm{DJ}_{\text {index }}$ は, 踏切時 間と䌦時間によって求められる。そこで本研究 では，各種スポーツ選手の $\mathrm{DJ}_{\text {index }}$ の優少が，踏 切時間と跳蛙時間のどちらに大きく影斑されるか について検討した，踏切時間は短いほど，跣躇時 間は長いほど，それぞれの諨题に対して優れてい

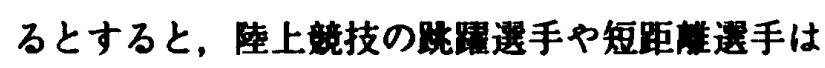
踏切時間，跳躈時間ともに優れているタイプ、ス

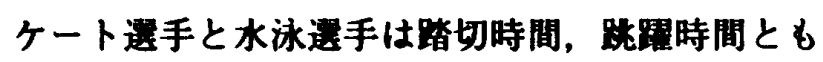
に少っているタイブ, 器械体操選手は踏切時間に 優れ，跳蹋時間に劣っているタイプ、スキージャ

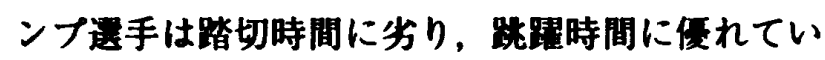
るタイブとして特堆づけられることが認められた

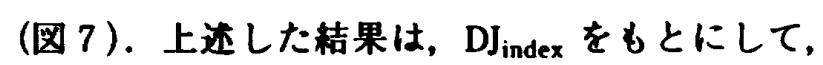
スポーツタレントを吐掘したり，トレーニング効 果を評価する場合には，その基磷になる踏切時間 と跳蹋時間を評価することが重要であることを示 している.

本研究では，バリスティックな伸張一短籍サイ クル運功の遂行能力を, 台高 $0.3 \mathrm{~m}$ からの浅い 滕曲げ功作のドロッフジャンブにおける $\mathrm{DJ}_{\text {index }}$ を用いて評価した。この DJ $\mathrm{J}_{\text {index }}$ は，踏切時間と 踒躍時間によって算出できるので，安佰な测定装 贯であるマットスイッチがあれば，だれでも，い つでも，どこでも，简単に测定できる。したがっ て、今啳、バリスティックな伸張一短縮サイクル 運功の遂行能力からみたスポーツ逜性やトレーニ ンク奻果を，手轻にしかも糖度よく测定・評価す る除には有用になると考えられる。

なお，本研究で用いた台高 $0.3 \mathrm{~m}$ からの浅い 


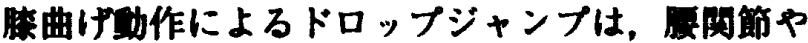

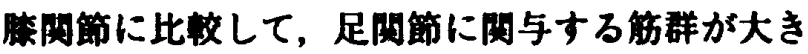

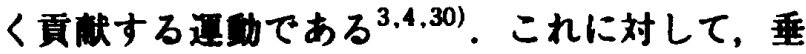

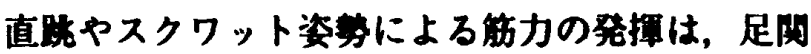

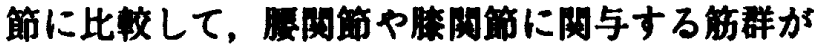
大きく貢姑する㯰功である，したがって，本砳究 で認められた各種スポーツ造手における下肢の筋 力およびパワー発掩に閶する特性には，㯰功遂行

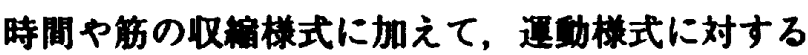
秛荅者の特性も反映していると考えられる。この ことについては，今後さらに検討する必要がある.

\section{要的}

本研究では，バリスティックな伸張 - 短編サイ クル運功の遂行能力を溂定・評価できる方法を作 成し，各種スポーツ造手における下肢の矨力およ びパワー発揮に関する特性について検討した。

1. 評価通動には，典型的な伸張一短編サイクル 運功であるドロッブジャンブを用いた．ドロッブ ジャンブの台高と滕曲什功作を，大学男子体育尃 攻学生10名を对象にして検討した。 その結果, $0.3 \mathrm{~m}$ の台高から浅い滕曲げ劫作によって行われ ろリバウンド型ドロッブジャンブは，段も短い踏

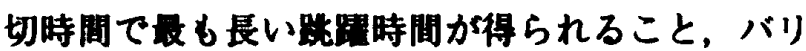
スティックな通的であること，安全性が高いこと などから評価罣版として逗切であることが認めら れた。

2.ドロップジャンプの遂行能力を評洒するため に，踏切時間 $\left(t_{c}\right)$ と跠蹋時間 $\left(t_{a}\right)$ を用いて, 踏切 中の平均力 $\left(F_{\text {index }}=\left|t_{a} / 2+\left(2 \cdot h_{d} / g\right)^{1 / 2}\right| / t_{c}+1\right]$ と 平均パワー $\left.\left[\mathrm{P}_{\text {index }}=\mathrm{kg} \cdot\left(\mathrm{t}_{\mathrm{a}} / 2\right)^{2}-2 \cdot \mathrm{h}_{\mathrm{d}}\right\} /\left(2 \cdot \mathrm{t}_{\mathrm{c}}\right)\right]$, および短い踏切時間の中で高い跳蹋高を獾得する 能力 $\left.[D]_{\text {index }}=\left(1 / 8 \cdot g \cdot t_{a}{ }^{2}\right) / t_{c}\right]$ の 3 つの指標を作成

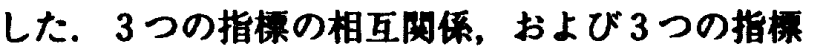

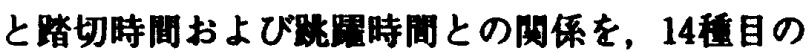
スポーツ選手男子93名を对象にして検討した。そ

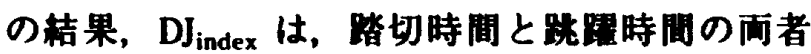
を反映した指槙であるとともに，平均力と平均パ ワーのいずれをも反映した指標であることなどか ら，バリスティックな伸偯一短編サイクル通助の 遂行能力を評価する最も遠切な指槚であることが
㑇められた。

3. 14種目のスボーツ選手における下肢の筋力お

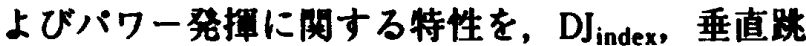
の跳躍高(CMJ-H)，およびスクワット姿繁による アイソメトリックな最大筋力 (S-MAX/BW) を比 䑤することによって模討した，その䊅果，実测值 を標望得点化した值をもとにすると，柀㰸者は大 きく A・B・Cの 3 群に分けられることが認めら

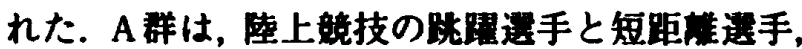
器械体撸盘および剣道選手などのように， $\mathrm{DJ}_{\mathrm{in}}$ 。 dex が最も高く，ついで, CMJ-H, S-MAX/BW の順に高くなるタイプであった。 B 群は，スケー 卜選手，スキージャンブ造手および水泳邆手など のように，A群とは逆のタイプであった．またC 群は，球技選手や陸上競技の長距崔選手のように， $\mathrm{DJ}_{\text {index }}, \mathrm{CMJ}-\mathrm{H}, \mathrm{S}-\mathrm{MAX} / \mathrm{BW}$ に影著な差のない タイプであった．なお，球技選手の中で，跳鞎や フットワークの能力に優れた選手は， $\mathrm{DJ}_{\text {index }}$ に 優れる傾向が認められた。

上述の結果は，各種スポーツ摬手における下肢 の筫力およびバワー発揮に関する特性を明らかに するためには，一般に行われている筇力やパワー の評価に加えて，本研究で対象にしたバリス ティックな伸張一短編サイクル運功の遂行能力も 評価することが有効であることを示している，そ のことによって，各熦スポーツ選手の下肢の筋力 およびパワー発揮からみたスポーツタレントの発 掘およびトレーニンク効果の評価は，より合理的 に実施できると考えられる，なお，DJ $\mathrm{J}_{\text {index }}$ の算 出に用いる踏切時間と踶躍時間は，マットスイッ チを用いて简単に，しかも精度よく睤定できるの

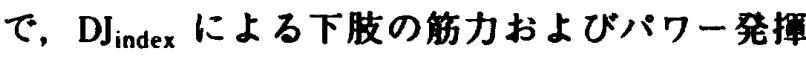
に関する評価は実用的であると考えられる。

\section{文新 (References)}

1) Asmussen, E, and Bonde-Petersen, F. (1974) Storage of elastic energy in skeletal muscles in man. Acta Physiol. Scand. $91:$ 385-392.

2) Bizzi, E., Polit, A. and Morsso, P. (1976) Mechan isms underlying achievement of final head position. J. Neurophysiol. $39: 435-444$.

3) Bobbert, M. F., Huijing. P. A. and Van Ingen Sche- 
nau, G. J. (1987) Drop Jumping I : The influence of jumping technique on the biomechanics of jumping. Med. Sci. Sports and Exerc. $19: 332-338$.

4) Bobbert. M. F., Huijing, P. A. and Van Ingen Schenau, G. J. (1987) Drop Jumping II : The influence of dropping height on the biomechanics of drop jumping. Med. Sci. Sports and Exerc. $19: 339-346$.

5) Bosco, C. and Komi, P. V. (1979) Potentiation of the mechanical behavior of the human skeletal muscle through prestretching. Acta Physiol. Scand. 106 : 467-472.

6) Bosco, C., Komi, P. V. and Ito, A. (1981) Prestretch potentiation of human skeletal muscle during ballistic movement. Acta Physiol. Scand. $111: 135-140$.

7) Bosco, C. and Viitasalo, J. T. (1982) Potentiation of myoelectric activity in human muscles in vertical jumps. Electromyogr. Clin. Neurophysiol. 22 : 549562.

8) Bosco, C., Viitasalo, J. T., Komi, P. V. and Luhtanen, P. (1982) Combined effect of elastic energy and myoelectrical potentiation during stretch-shortening cycle exercise. Acta Physiol. Scand. $114: 557-565$.

9) Brooks, V. B. and Thach, W. T. (1981) Cerebellar control of posture and movement. In : Brooks, V. B. (Eds.) Handbook of physiology. The nervous system, vol. II, part 2. American physiological Society : Bethesds. pp. 889-891.

10) Capaday, C. and Stein, R. B. (1987) Difference in the amplitude of human soleus $\mathrm{H}$-reflex during walking and running. J. Physiol. $392:$ 513-522.

11) Cavagna, G. A., Saibene, F. P. and Margaria, R. (1965) Effect of negative work on the amount of positive work performed by an isolated muscle. J. Appl. Physiol. $20: 157-158$.

12) Cavagna, G. A., Dusman, B. and Margaria, R. (1968) Positive work done by a previously stretched muscle. J. Appl. Physiol. $24: 21-32$.

13) Chapman, A. E. and Caldwell, G. E. (1985) The use of muscle stretch in inertial loading. Biomechanics N-A. 44-49.

14) Chapman, A. E., Caldwell, G. E. and Selbie, W. S. (1985) Mechanical output following muscle stretch in forearm supination against inertial loads. J. Appl. Physiol. 59 : 78-86.

15) Desmedt, J. E. and Godaux, E. (1977) Ballistic con traction in man: Characteristic recruitment pattern of single motor unit of tibialis anterior muscles. J.
Physiol. $264: 673-693$.

16) Desmedt. J. E. and Godaux, E. (1978) Ballistic skilled movements : Load compensation and patterning of the motor commands. Desmedt, J. E. (Eds.) Cerebral motor control in man : Long loop mechanism. Prog. Clin. Neurophysiol. $4: 21-55$.

17) Desmedt, J. E. and Godaux, E. (1979) Voluntary motor commands in human ballistic movements. Ann. Neurol. $5: 415-421$.

18) Gollhofer, A., Strojnik, W., Rapp, W. and Schweizer, L. (1992) Behaviour of triceps surae muscle-tendon complex in different jump condition. Eur. J. Appl. Physiol. 64 : 283-291.

19) Hallett, M. (1975) EMG analysis of steleotyped voluntary movement in man. J. Neurosurg. Phychiat. $38: 1154-1162$.

20) Hay. J. G. (1973) The Hay technique ultimate in jump style. Athletic Journal. $53(7): 113-115$.

21) Karayannis, M. (1978) A Cinematographical analysis of long jump take off : The best nine long jumpers at the 1974 NCAA championship. Track and Field Quart. Review 78:17-24.

22）腾田 茂・酒井俊郎・河原志津子（1988）プライオ メトリックスに间する基碳的研究一穜技種目別にみ たデブスジャンプの至道回数について一．昭和62年 度日本体青協会スボーツ科学研究辄告 №.Vプ ライオメトリックリアクティフ筇カトレーニングに 関する研究 一第 1 報一，44-55.

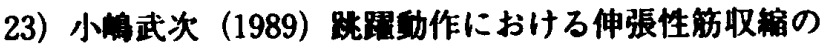
意義. J. J. Sports Sci. $3: 123-129$.

24) Komi, P. V. and Buskirk, E. R. (1972) Effect of eccentric and concentric muscle conditioning on tension and electrical activity of human muscle. Ergonomics. $15: 427-434$.

25) Komi, P. V. and Bosco, C. (1978) Utilization of stored elastic energy in leg extensor muscles by men and women. Med. Sci. Sports and Exerc. 10 : 261-265.

26) Marsden, G. D (1976) Servoactin in human thumb. J. Physiol. $257: 1-44$.

27) Moritani, T., Oddsson, L. and Thorstensson, A. (1990) Differences in modulation of the gastrocnemius and soleus $\mathrm{H}$-reflexes during hopping in man. Acta Physiol. Scand. 138 : 575-576.

28) Smith, J. L. (1977) EMG of slow and fast ankle extensors of cat during posture, locomotion and jumping. J. Neurophysiol. $40: 503-513$. 
29) Smith, J. L. (1980) Rapid ankle extension during paw shakes: Selective recruitment of fast ankle extensors. J. Neurophysiol. $13: 612-620$.

30）高松 恶・图子浩二・会田宏・吉田亨・石島 策 (1989) デブスジャンブにおける台高と踏切中の

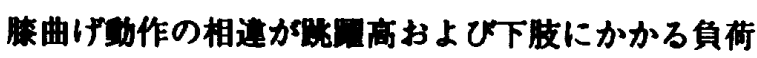
特性に及ほす影管. 昭和63年度日本体青咕会スポー ツ科学研究竍告 No. IX プライオメトリックリアク ティフ筋カトレーニングに间する研究一第 2 䇉一, 46-55.

31）高松 莎・会田 宏・图子浩二（1991）Isometric お よび eccentric な子傹䋈張が时屈曲速度に及はす影

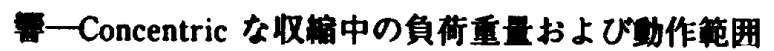
に着目して一。体青学研究 $36: 127-139$.

32) Viitasalo, J. T. (1984) Electromechanical behaviour of the knee extensor musculature in maximal isometric and concentric contractions and in jumping. Electromyogr. clin. Neurophysiol. $24: 293-303$.

33）米田縋武（1989）すばやい力発揮の制彻. J. J. Sports Sci. $10: 657-662$.

(平成 4 年 7 月23日受付) 